\title{
Open-cell polyurethane foams based on modified used cooking oil ${ }^{*}$
}

\author{
Maria Kurańska),**), Krzysztof Polaczek1), Monika Auguścik-Królikowska ${ }^{2)}$, Aleksander Prociak $^{11, * *)}$, \\ Joanna Ryszkowska ${ }^{2)}$
}

DOI: dx.doi.org/10.14314/polimery.2020.3.6

\begin{abstract}
The present paper reports an innovative, sustainable approach in accordance with the rules of Circular Economy in the synthesis of open-cell polyurethane foams. The materials were prepared with biopolyols from a used cooking oil. The hydroxyl values of the biopolyols were ca. 100, 200 and $250 \mathrm{mg}$ $\mathrm{KOH} / \mathrm{g}$. In the next step, the three polyurethane biofoams were modified with a flame retardant in order to decrease their flammability. The influence of the hydroxyl values of the biopolyols on the reactivity of the systems, cellular structures, mechanical and thermal properties of the biofoams was investigated. The most beneficial properties were obtained for open-cell polyurethane foams prepared using biopolyol characterized by hydroxyl value $200 \mathrm{mg} \mathrm{KOH} / \mathrm{g}$.
\end{abstract}

Keywords: open-cell polyurethane foams, used cooking oil, biopolyol, Circular Economy.

\section{Otwartokomórkowe pianki poliuretanowe otrzymywane z zastosowaniem modyfikowanego oleju posmażalniczego}

Streszczenie: $\mathrm{W}$ artykule przedstawiono innowacyjne i zrównoważone podejście, zgodne z zasadami Gospodarki o Obiegu Zamkniętym, do syntezy otwartokomórkowych pianek poliuretanowych. Do wytworzenia pianek użyto biopoliole o liczbie hydroksylowej 100, 200 i $250 \mathrm{mg} \mathrm{KOH/g} \mathrm{otrzymane}$ z oleju posmażalniczego. Na kolejnym etapie badań wytworzono pianki otwartokomórkowe z zastosowaniem czynnika zmniejszającego ich palność. Dokonano analizy wpływu liczby hydroksylowej biopolioli na reaktywność systemów poliuretanowych, strukturę komórkową oraz właściwości mechaniczne i termiczne otrzymanych biopianek. Najkorzystniejsze właściwości użytkowe wykazywały otwartokomórkowe pianki poliuretanowe otrzymane z biopoliolu o liczbie hydroksylowej $200 \mathrm{mg} \mathrm{KOH} / \mathrm{g}$.

Słowa kluczowe: otwartokomórkowe pianki poliuretanowe, olej posmażalniczy, biopoliol, Gospodarka o Obiegu Zamkniętym.

Polyurethanes (PURs) make up a broad type of polymeric materials having the urethane bond as a common group. PURs are prepared in the reaction of polyols and isocyanates as well as additives. These polymers are known for their versatility because they can be applied as solid or porous materials. Porous materials are classified as flexible, semi-rigid or rigid foams [1].

Rigid PUR foams are manufactured on an industrial scale using a variety of methods, such as the continuous

\footnotetext{
1) Cracow University of Technology, Department of Chemistry and Technology of Polymers, Warszawska 24, 31-155 Kraków, Poland.

2) Warsaw University of Technology, Faculty of Materials Science, Wołoska 141, 02-507 Warszawa, Poland.

*) The article was presented at the Pomerania-Plast 2019 Conference, June 5-7, 2019, Międzyzdroje, Poland.

**) Authors for correspondence:

maria.kuranska@gmail.com, aprociak@pk.edu.pl
}

method of making blocks, plates, continuous or semi-continuous production of pre-insulated pipes or spraying directly at the place of use. Spray PUR foams are globally one of the fastest-growing building insulation products. Spray insulation foams are divided into two categories, "open-cell" or "closed-cell" and each type is different in terms of the structure, where it should be applied, as well as the performance and properties.

Closed-cell foams can be used as roof insulation, substructure, floors. The apparent density of such materials is in the range $34-50 \mathrm{~kg} / \mathrm{m}^{3}$, heat conductivity $0.020-0.022 \mathrm{~W} /(\mathrm{m} \cdot \mathrm{K})$, and compressive strength 190-380 kPa [2-4].

In the case of open-cell PUR foams the properties are completely different. This comes as a result of an opencell structure which has an influence on the thermal conductivity [0.037-0.039 $\mathrm{W} /(\mathrm{m} \cdot \mathrm{K})]$ as well as compressive strength $(c a .10 \mathrm{kPa})$. Mechanical properties are also connected with the apparent density of an open-cell foam 
which is in the range of 7-14 kg/m $3 \mathrm{~m}^{3}$ [5-7]. Such materials are characterized by by a low water vapour diffusion resistance factor thanks to which moisture is not retained in the insulating layer, allowing its application in the attics of buildings.

The latest trends in the field of chemical technology focus on the design of polymers and polymer composites with the use of renewable raw materials or waste [8-11]. In the last several decades researches have concentrated on the modification of natural oils and their application in the synthesis of PUR foams. Polyols commercially used for the preparation of PURs are made from chemical intermediates derived from petroleum. According to the new regulations of the European Union associated with Circular Economy, the value of products, materials and resources should be maintained in economy for as long as possible and the generation of waste should be minimized [12]. Considering the above-mentioned aspects as well as the cleaner production, research was undertaken on the chemical modification of a used cooking oil and use of the resultant biocomponent in the preparation of open-cell polyurethane foams.

In the literature there is little research focused on the modification of open-cell rigid/semi-rigid PUR foams modified with biopolyols characterized by an apparent density in the range of 7-35 kg/m $\mathrm{m}^{3}$. Marcovich [13] compared foams modified with two types of biopolyols. The biopolyols were synthesized by the epoxidation oxirane ring-opening process using water and diethylene glycol. The hydroxyl values of those polyols were 102 and $147 \mathrm{mg} \mathrm{KOH} / \mathrm{g}$, respectively. The reference foam was modified by a replacement of $70 \mathrm{wt} \%$ of the petrochemical polyol by a biopolyol with a hydroxyl value of 102 or $147 \mathrm{mg} \mathrm{KOH} / \mathrm{g}$. It was concluded that the reactivity of the PUR system modified with the biopolyol with the hydroxyl value $147 \mathrm{mg} \mathrm{KOH} / \mathrm{g}$ was higher than the reactivity of the system modified with the biopolyol with lower hydroxyl value.

The influence of the chemical structure, hydroxyl value, viscosity, functionality and position of hydroxyl groups in triglyceride chains on the foaming process as well as other useful properties was confirmed by other researchers [14-16]. The cited works concern mainly closed-cell foams with apparent densities above $30 \mathrm{~kg} / \mathrm{m}^{3}$.

This paper presents the influence of three different biopolyols with different hydroxyl values on the cell structure and physical-mechanical properties of open-cell polyurethane foams with apparent density below $20 \mathrm{~kg} / \mathrm{m}^{3}$. The biopolyols used in the preparation of tested materials were obtained using a post-frying oil. According to the latest trends related to the Circular Economy, no petrochemical polyols were used in this work. From application point of view it is important to offer heat insulating materials with low flammability therefore biofoams modified by addition of flame retardant were also investigated.

\section{EXPERIMENTAL PART}

\section{Materials}

In the synthesis of the open-cell PUR foams, the following raw materials have been used:

- Ongronat ${ }^{\circledR} 2100$ (oligomeric methylene diphenyl diisocyanate) containing $31 \mathrm{wt} \%$ of free isocyanate groups supplied by the company BorsodChem,

- polyols - the three biopolyols (POL_100; POL_200; POL_250) were prepared at Cracow University of Technology. The characteristics of the three types of biopolyols are presented in the later text,

- catalysts and surfactant system - know how,

- water was used as a blowing agent,

- flame retardant - triethyl phosphate (TEP).

\section{Preparation of foams}

The PUR foams were obtained through mixing component A (biopolyols, catalyst, surfactant, water) and component $\mathrm{B}$ (isocyanate). The formulations of the foams prepared are shown in Table 1.

\section{Methods of testing}

Titration methods were used for the evaluation of the epoxy and hydroxyl values $\left(\mathrm{OH}_{\mathrm{val}}\right)$. The content of epoxy groups $\left(\mathrm{E}_{\mathrm{val}}\right)$ was determined according to the PN-87/C-89085/13 standard and the hydroxyl value was found according to the standard PN-93/C-89052/03.

A FT-IR spectroscopy was performed using an FT-IR SPECTRUM 65 spectrometer (PerkinElmer) equipped with an accessory ATR Miracle with a ZnSe crystal. The FT-IR spectra shown below correspond to the middle infrared range $\left(4000-400 \mathrm{~cm}^{-1}\right)$.

$\mathrm{T}$ a b l e 1. Formulations of the open-cell PUR foams

\begin{tabular}{c|c|c|c|c|c|c}
\hline Component, g & PU_100 & PU_200 & PU_250 & PU_100_FR & PU_200_FR & PU_250_FR \\
\hline POL_100 & 100 & - & - & 100 & - & - \\
POL_200 & - & 100 & - & - & 100 & - \\
POL_250 & - & - & 100 & - & 20 & 20 \\
Flame retardant & - & - & - & 15 & 15 & 100 \\
Water & 15 & 15 & 15 & 1.0 & 1.0 & 1.0 \\
Isocyanate index & 1.0 & 1.0 & 1.0 & & \\
\hline
\end{tabular}


The number average molecular weight $(\mathrm{Mn})$, weight average molecular weight $(M w)$ and dispersity $(D)$ were determined by a gel permeation chromatography (GPC) analysis. GPC measurements were carried out using a Knauer chromatograph equipped with a PLgel MIXED-E column for the analysis of oligomers and a refractometric detector. The calibration was done using the polystyrene standards. Tetrahydrofuran was used as an eluent at a $0.8 \mathrm{~cm}^{3} / \mathrm{min}$ flow rate at room temperature.

The viscosity $(\eta)$ was determined using a rotational rheometer HAAKE MARS III (Thermo Scientific) at $25{ }^{\circ} \mathrm{C}$. The control rate mode was used in the plate-plate arrangement with the plates having a diameter of $20 \mathrm{~mm}$ and rotation speeds of 100 cycles/min.

The foaming process was analyzed using FOAMAT equipment. The samples were conditioned at $22{ }^{\circ} \mathrm{C}$ and $50 \%$ relative humidity for $24 \mathrm{~h}$.

The morphology of cells was analyzed using a scanning electron microscope (Hitachi TM3000). The closed cell content (CC) was measured according to ISO 4590.

The apparent density $(d)$, compressive strength $(\sigma)$, thermal conductivity $(\lambda)$ of the PUR foams were determined according to ISO 845, ISO 826, ISO 8301, respectively.

The presence of characteristic bonds in the PUR foams and the degree of phase separation were found based on infrared absorption spectra recorded using a Nicolet 6700 (Thermo Electron Corporation) FT-IR spectrophotometer equipped with an ATR accessory [17].

The hydrogen bonding index $(R)$ and content of rigid urethane segments in the structure of the synthesized materials can be used to calculate the phase separation degree (DSP) based on the FT-IR results. $R$ value was calculated using the following equation: $R=\left(A_{1}+A_{2}\right) /\left(A_{3}+A_{4}\right)$, where $A_{1}, A_{2}$-a range of bands corresponding to hydrogen bonded carbonyl bonding in urea groups (1640-1686 $\left.\mathrm{cm}^{-1}\right)$ and urethane groups (1705-1724 $\left.\mathrm{cm}^{-1}\right) ; A_{3^{\prime}} A_{4}$ - bands corresponding to carbonyl not bound by hydrogen in urea groups (1690-1702 $\mathrm{cm}^{-1}$ ) and urethane groups $\left(1732-1760^{-1}\right)$ $[18,19]$. The Gaussian curve fitting method applying OMNIC 8.2 software was used in order to estimate the intensity of the bands under consideration.

The coefficient of thermal conductivity was measured using a Laser Comp Heat Flow Instrument Fox 200. The measurements were performed at an average temperature of $10{ }^{\circ} \mathrm{C}$ (the temperature of the cold plate was $0{ }^{\circ} \mathrm{C}$ and that of the warm plate was $20^{\circ} \mathrm{C}$ ).

The differential scanning calorimetry (DSC) measurements were performed using the differential scanning calorimeter DSC Q1000 (TA Instruments) under a helium atmosphere and using hermetic aluminum pans. Samples $(5 \pm 0.2 \mathrm{mg})$ were heated at the $10 \mathrm{deg} / \mathrm{min}$ rate in the temperature range $-90^{\circ} \mathrm{C}$ to $220^{\circ} \mathrm{C}$ (first cycle) then cooled at the $5 \mathrm{deg} / \mathrm{min}$ rate in the temperature range $220{ }^{\circ} \mathrm{C}$ to $-90{ }^{\circ} \mathrm{C}$ (second cycle) and finally heated at the $10 \mathrm{deg} / \mathrm{min}$ rate in the temperature range $-90^{\circ} \mathrm{C}$ to $220^{\circ} \mathrm{C}$ (third cycle).

The thermogravimetric analysis (TGA) was performed with the Q500 analyzer (TA Instruments) using $10 \pm 1 \mathrm{mg}$ samples which were heated from $25^{\circ} \mathrm{C}$ to $1000{ }^{\circ} \mathrm{C}$ at the rate of $10 \mathrm{deg} / \mathrm{min}$. The results were processed using the Universal Analysis 2000 software (4.7A version, TA Instruments). The measurements were performed in an air atmosphere.

\section{RESULTS AND DISCUSSION}

In order to synthesize biopolyols with different $\mathrm{OH}_{\text {val' }}$ three types of epoxydized oils characterized by $\mathrm{E}_{\mathrm{val}}$ in the range $0.1-0.3 \mathrm{~mol} / 100 \mathrm{~g}$ were prepared. Table 2 presents the properties of UCO (used cooking oil) and epoxidized oils obtained.

The obtained epoxy oils are mainly different in terms of $\mathrm{E}_{\mathrm{val}}$. Figure 1 shows a chromatogram of UCO and epoxy oils.

During the frying process, many chemical reactions occur in vegetable oils which affect their chemical structures [20, 21]. These reactions may include reactions leading to an increase in the molar mass of the oils (poly-

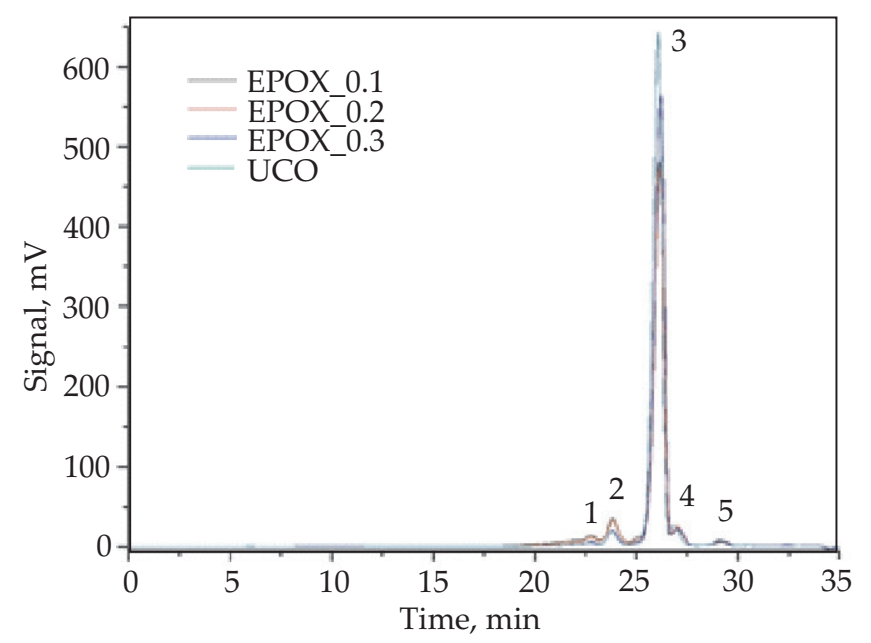

Fig. 1. GPC chromatograms of UCO and epoxidized oils

T a b l e 2. Properties of used cooking oil and epoxidized oils

\begin{tabular}{c|c|c|c|c}
\hline Properties & UCO & EPOX_0.1 & EPOX_0.2 & EPOX_0.3 \\
\hline $\mathrm{E}_{\mathrm{val}} \mathrm{mol} / \mathrm{100g}$ & 0 & 0.095 & 0.212 & 0.320 \\
$\mathrm{H}_{2} \mathrm{O}, \mathrm{wt} \%$ & 0.04 & 0.06 & 0.10 & 0.19 \\
$\mathrm{Mn}, \mathrm{g} / \mathrm{mol}$ & 917 & 947 & 941 & 878 \\
$M w, \mathrm{~g} / \mathrm{mol}$ & 939 & 1113 & 1070 & 936 \\
$Ð$ & 1.02 & 1.18 & 1.14 & 1.07 \\
\hline
\end{tabular}


T a b l e 3. Properties of biopolyols

\begin{tabular}{c|c|c|c}
\hline Properties & POL_100 & POL_200 & POL_250 \\
\hline $\mathrm{OH}_{\mathrm{val}^{\prime}} \mathrm{mg} \mathrm{KOH/g}$ & 113 & 198 & 254 \\
$\eta, \mathrm{mPa} \cdot \mathrm{s}$ & 670 & 4196 & 22390 \\
$\mathrm{H}_{2} \mathrm{O}, \mathrm{wt} \%$ & 0.15 & 0.22 & 0.24 \\
$\mathrm{Mn}, \mathrm{g} / \mathrm{mol}$ & 1101 & 1157 & 1218 \\
$\mathrm{Mw}, \mathrm{g} / \mathrm{mol}$ & 2213 & 4174 & 7099 \\
$Ð$ & 2.01 & 3.61 & 5.83 \\
\hline
\end{tabular}

merization reactions). The presence of such products in the UCOs is evidenced by the presence of a peak with a retention time of about 24 minutes and a molar mass being twice the molar mass of the triglyceride. The reactions during the frying may also lead to a decrease in the molar mass of the oils, including the release of free fatty acids (FFAs). The presence of diacylglycerols and monoacylglycerols can be identified as low intensity peaks with retention times of 27 (peak 4) and 29 (peak 5) minutes, respectively (Fig. 1).

During the epoxidation reactions, side reactions such as opening oxirane rings in the reaction with water or acid, as well as the reactions with hydroxy and/or acetoxy derivatives may occur leading to dimerization reactions [22]. These reactions result in a significant increase in the viscosity of products. On GPC chromatograms of the epoxidized oils, these products are visible in the form of peaks with masses corresponding to di-, tri- and tetramers of triglyceride. In the next stage of the research the epoxidized oils were hydroxylated using diethylene glycol. Table 3 presents the properties of the biopolyols obtained.

The biopolyols were characterized by $\mathrm{OH}_{\mathrm{VAL}}$ 113, 198 and $254 \mathrm{mg} \mathrm{KOH} / \mathrm{g}$, respectively. An increase in the molar mass and dispersity is visible in relation to the increase in $\mathrm{OH}_{\mathrm{VAL}}$ of biopolyols. The chromatograms of the biopolyols GPC are shown in Fig. 2 and in Table 4 shows the average molar masses and peak surfaces, which can

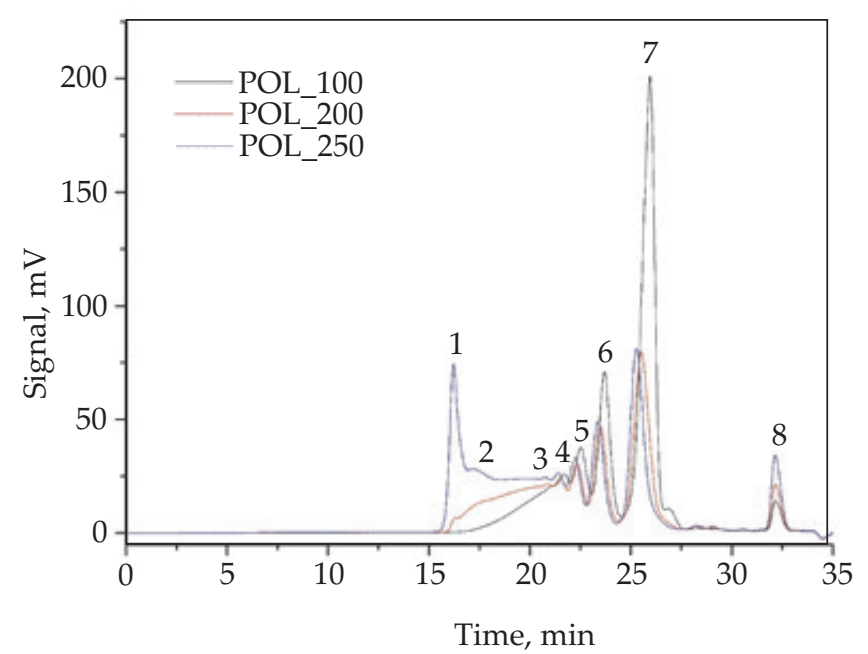

Fig. 2. GPC chromatograms of biopolyols
T a b l e 4. Characteristics of biopolyol peaks

\begin{tabular}{c|c|c|c|c|c|c|c|c|c}
\hline \multirow{2}{*}{ Symbol } & \multirow{2}{*}{ Properties } & \multicolumn{7}{|c}{ Peak } \\
\cline { 5 - 10 } & & 1 & 2 & 3 & 4 & 5 & 6 & 7 & 8 \\
\hline \multirow{3}{*}{ POL_100 } & $M n$ & - & - & - & 5137 & 2803 & 1921 & 959 & 126 \\
& Mrea, \% & - & - & - & 5892 & 2823 & 1938 & 976 & 126 \\
& $M n$ & - & - & 7845 & 3898 & 2968 & 2034 & 1044 & 126 \\
\hline \multirow{3}{*}{ POL_200 } & $M w$ & - & - & 9403 & 3915 & 2988 & 2054 & 1067 & 127 \\
& Area, \% & - & - & 31.6 & 6.7 & 9.3 & 14.9 & 31.8 & 4.5 \\
\hline \multirow{2}{*}{ POL_250 } & $M n$ & 20280 & 13402 & 6627 & 3979 & 3071 & 2117 & 1118 & 126 \\
& Mw & 20432 & 13647 & 7058 & 3993 & 3091 & 2137 & 1137 & 127 \\
& Area, $\%$ & 15.4 & 12.1 & 20.3 & 5.0 & 11.4 & 21.8 & 22.0 & 5.9 \\
\hline
\end{tabular}

be interpreted as the percentage of a particular fraction in the product analyzed.

Increasing the molar mass of the biopolyol leads to a significant increase in its viscosity as well as dispersity. It is caused by oligomerization reactions. The three dominant peaks correspond to triglycerides (5), diglycerides (6) and monoglycerides (7). Peak 8 with a retention time of $32 \mathrm{~min}$ is derived from the unreacted diethylene glycol [23]. The highest concentration of diethyene glycol was noticed for POL_250, despite the fact, the same molar ratio of diethylene glycol to epoxy rings was used in synthesis of biopolyols. Such an effect can be associated with a higher tendency to oligomerization reactions in the case of the epoxidized oils characterized by a higher epoxy rings content (higher $\mathrm{E}_{\mathrm{val}}$ ). This hypothesis can be also confirmed by the highest content of water in the case of POL_250.

The biopolyols with different characteristics were used for the preparation of open-cell PUR foams. It was confirmed that the modification of PUR system with biocomponents such as biopolyols or fillers has an impact on the system's reactivity [13, 14, 24, 25]. In order to determine the influence of the different structures of the biopolyols on the foaming process, a proper analysis was performed (Fig. 2). Firstly, the analysis was done for the systems with the same content of the catalyst. Figure 3 shows the changes in the dielectric polarization (Fig. 3a) and temperature (Fig. 3b) of the PUR reaction mixtures.

The reactivity of a PUR mixture is reflected by changes of dielectric polarization, which decreases as an effect of the progress of the reaction of biopolyol and water with the isocyanate component [13]. All the formulations exhibit the similar decreases in the dielectric polarization. It can be stated that the difference in the biopolyols' $\mathrm{OH}_{\text {val }}$ does not significantly change the reactivity of the systems under investigation.

The PUR formation reactions are highly exothermic. The rate of temperature rise determines the reactivity of PUR systems [26]. It was observed that PU_200 had the highest temperature during the foaming process. This effect can be associated with the cell structure of the foams. During the preparation of the open-cell PUR foams with 
a)

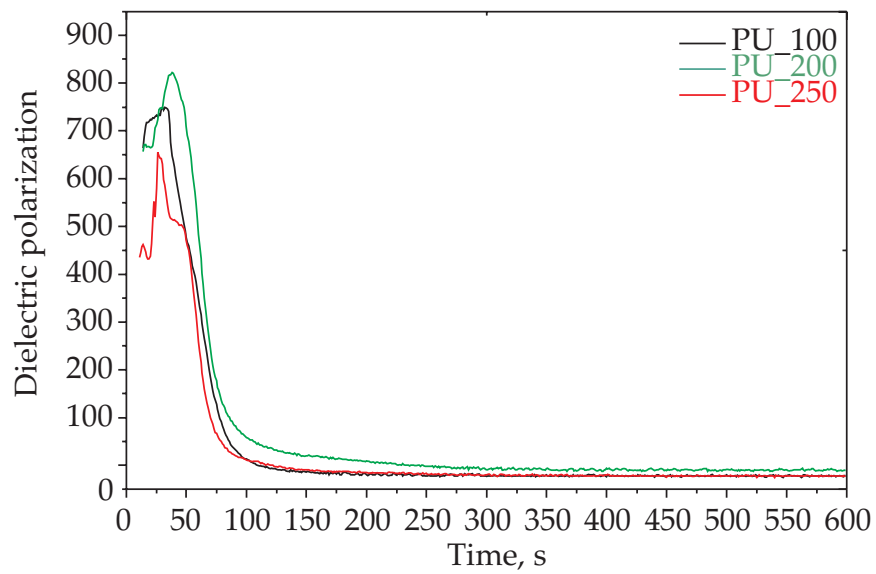

b)

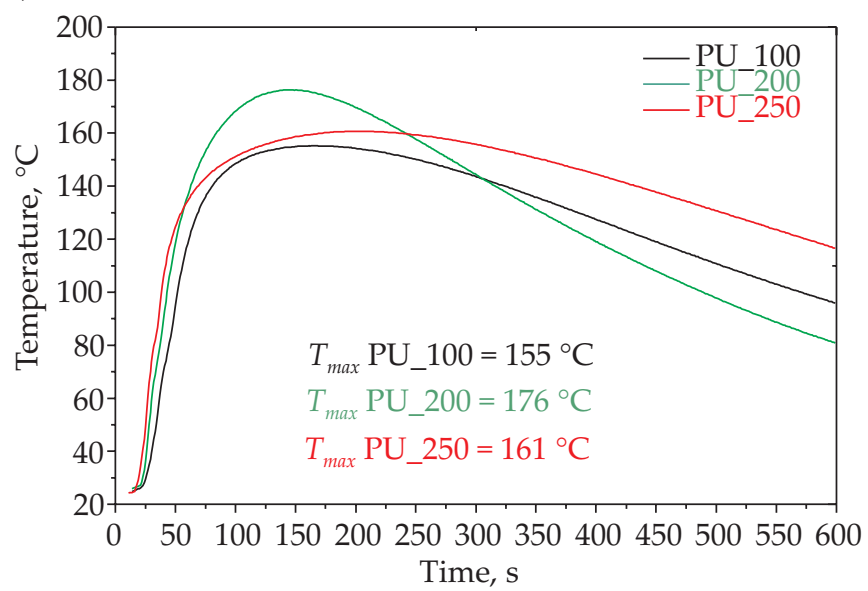

Fig. 3. The influence of biopolyols with different characteristics on: a) the dielectric polarization, b) temperature of the PUR systems (with the same content of catalyst) during the foaming process

an apparent density of $c a .12 \mathrm{~kg} / \mathrm{m}^{3}$ the PUR system increases its volume ca. 100 times. In this case, the catalytic system must be individually selected for the properties of the components to ensure the proper course of the foaming and gelation reactions. Imbalance between these reactions causes a collapse of the foamed materials. This effect was observed for the PU_100 system and partially also for PU_250. In the case of these two samples, lower maximal temperatures were measured, which was a)

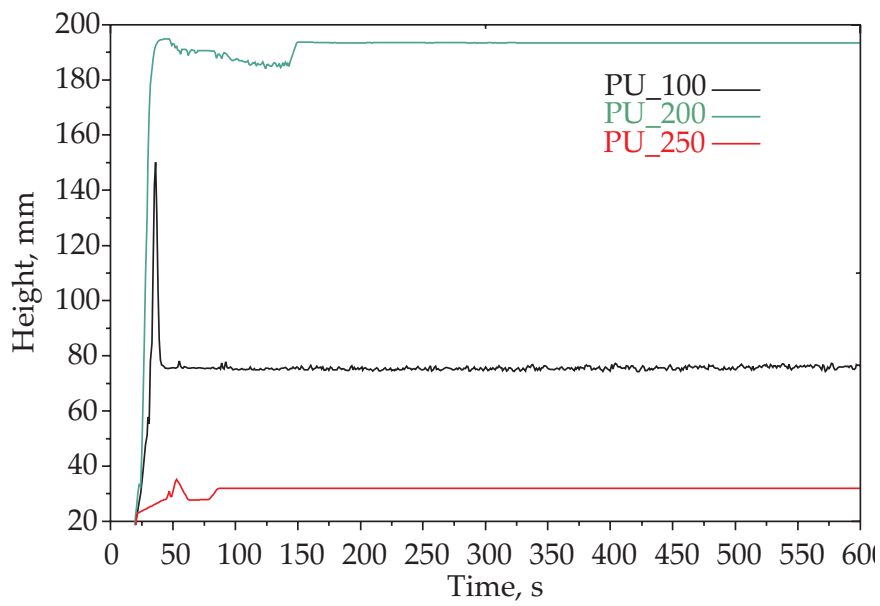

b)

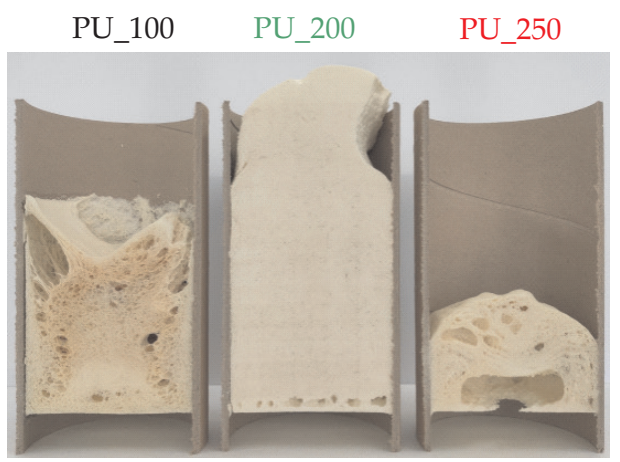

Fig. 4. The influence of biopolyols with different characteristics on the foam: a) height, b) structure probably an effect of foam collapse. The differences in the heights and structures of the foams compared here are shown in Fig 4.

In order to obtain materials with suitable cell structures, catalyst compositions were selected for each reaction mixture (containing different biopolyols). The same

a)

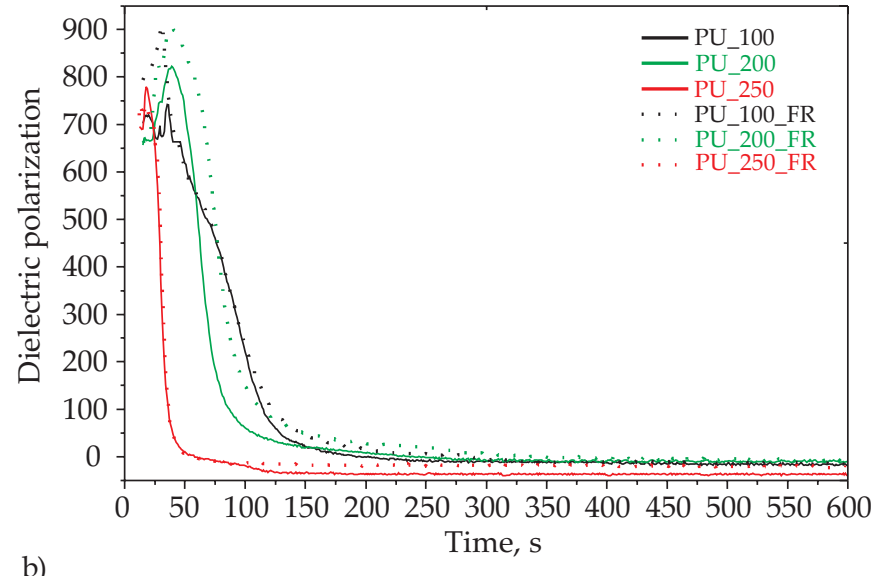

b)

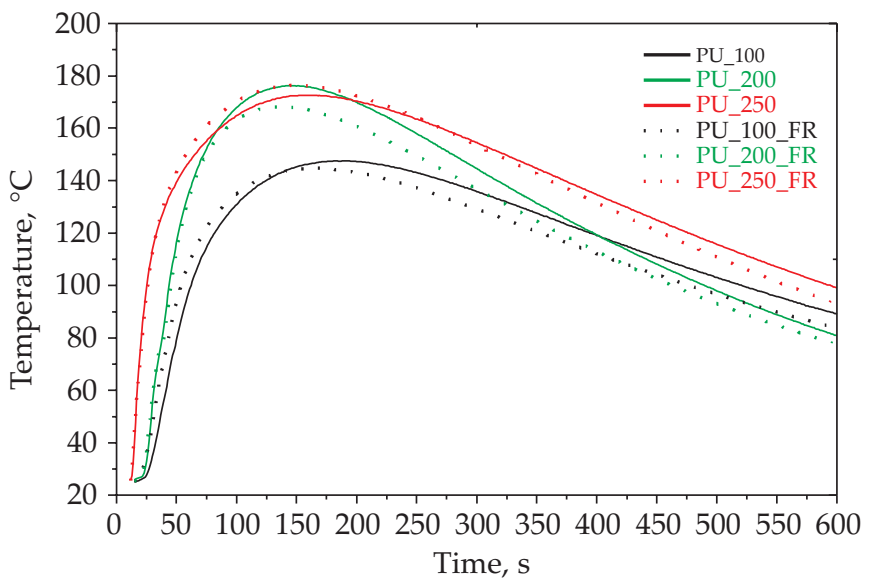

Fig. 5. The influence of biopolyols with different characteristics on: a) the dielectric polarization, b) temperature of the PUR systems (with the selected catalyst compositions) during the foaming process 

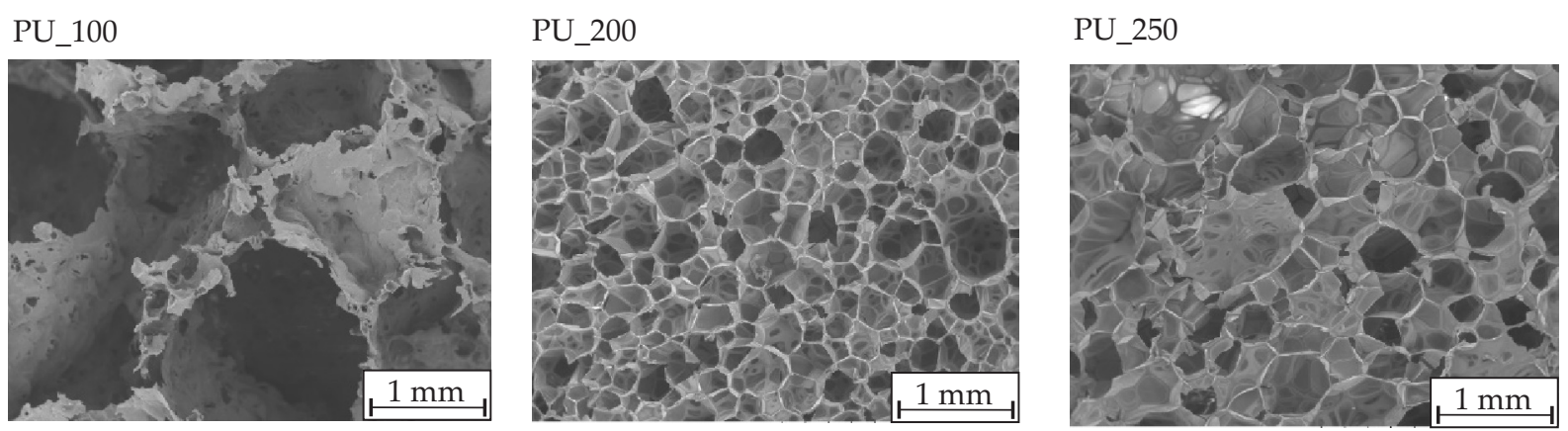

PU_100_FR

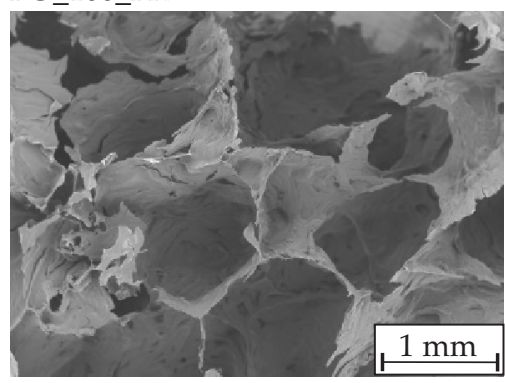

PU_200_FR

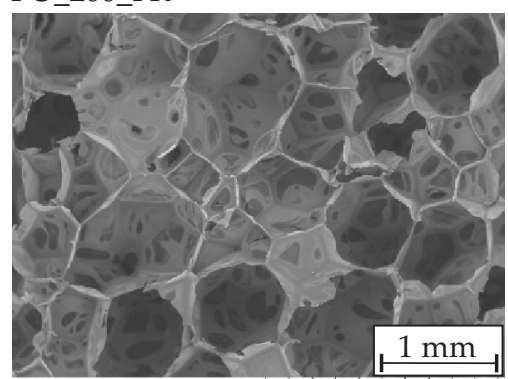

PU_250_FR

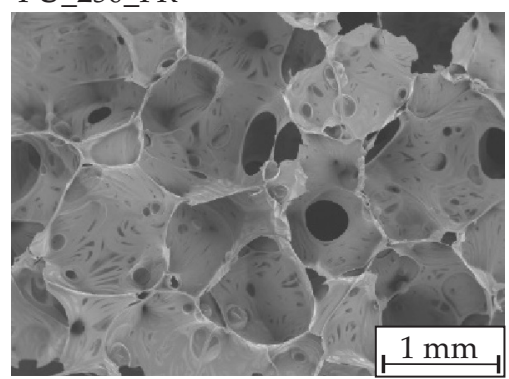

Fig. 6. SEM images of open-cell PUR foams

catalyst compositions were used for both types of PUR systems with and without a flame retardant. The changes in the dielectric polarization and temperature of the reaction mixtures with the selected catalyst compositions are shown in Fig. 5.

Unexpectedly, it was noticed that the introduction of the additive flame retardant did not have an influence on the system's reactivity. The reactivity of the reaction mixtures of the two PUR systems correlated with the $\mathrm{OH}_{\text {val }}$ of the biopolyol used. The higher the $\mathrm{OH}_{\text {val }}$ of the biopolyol, the higher the system's reactivity. However, there is no a unequivocal correlation between the systems' reactivity and the cell structure of the foams. The SEM microphotographs of the foams with and without the flame retardant are shown in Fig. 6.

It was observed that the PU_100 and PU_100_FR foams were characterized by the most irregular shapes of cells and the cell sizes were much more larger in comparison to the PU_200 and PU_250 samples. This effect can be associated with the lowest reactivity of the systems PU_100 and PU_100_FR.

Rigid PUR foams with closed-cell structures that are commercially available are characterized by apparent densities in the range of $35-50 \mathrm{~kg} / \mathrm{m}^{3}$ [27]. Apparent densities of open-cell
PUR foams is lower than $20 \mathrm{~kg} / \mathrm{m}^{3}$. Selected properties of the PUR foams studied here are shown in Table 5. The PUR materials had apparent densities below $20 \mathrm{~kg} / \mathrm{m}^{3}$ and were mostly characterized by contents of closed cell lower than $10 \%$ and such materials can be classified as open-cell foams.

The most beneficial mechanical and heat insulating properties were found for materials based on biopolyol POL_200. This effect is associated with relatively high values of hydroxyl number and functionality as well as low content oligomers, which influence on foaming process and a possibility to obtain products with uniform cellular structure in the case of PU_200. The addition of flame retardant caused a decrease of cells density (bigger cells) and this had the effect on lower mechanical compressive strength as well as higher coefficient of thermal conductivity.

FT-IR spectra recorded for the foams PU_100, PU_200, PU_250, contained biopolyols POL_100, POL_200 and POL_250 respectively, are shown in Fig. 7.

The characteristic peaks indicating the formation of urethane linkages were observed. A signals at $3336 \mathrm{~cm}^{-1}$ (stretching vibrations) and $1508 \mathrm{~cm}^{-1}$ (bending vibrations) are characteristic for $\mathrm{N}-\mathrm{H}$ group. They are urethane carbonyl $(\mathrm{OC}=\mathrm{O})$ vibration at $1701 \mathrm{~cm}^{-1}$ and $\mathrm{C}-\mathrm{O}$ vibration at $1068 \mathrm{~cm}^{-1}$ [28]. The absorption bands at $1228 \mathrm{~cm}^{-1}$ are

T a b l e 5. Properties of PUR foams

\begin{tabular}{c|c|c|c|c|c|c}
\hline Properties & PU_100 & PU_100_FR & PU_200 & PU_200_FR & PU_250 & PU_250_FR \\
\hline CC, \% & 4.8 & 4.1 & 4.6 & 6.5 & 40.2 & 9.9 \\
$d, \mathrm{~kg} / \mathrm{m}^{3}$ & 18.8 & 15.9 & 13.0 & 12.5 & 13.9 & 18.4 \\
$\lambda, \mathrm{mW} /(\mathrm{m} \cdot \mathrm{K})$ & 44.52 & 44.49 & 36.76 & 41.74 & 38.65 & 37.74 \\
$\sigma, \mathrm{kPa}$ & $9.93 \pm 1.24$ & $8.38 \pm 0.19$ & $38.96 \pm 8.56$ & $21.16 \pm 4.54$ & $27.18 \pm 6.70$ & $40.41 \pm 1.87$ \\
\hline
\end{tabular}




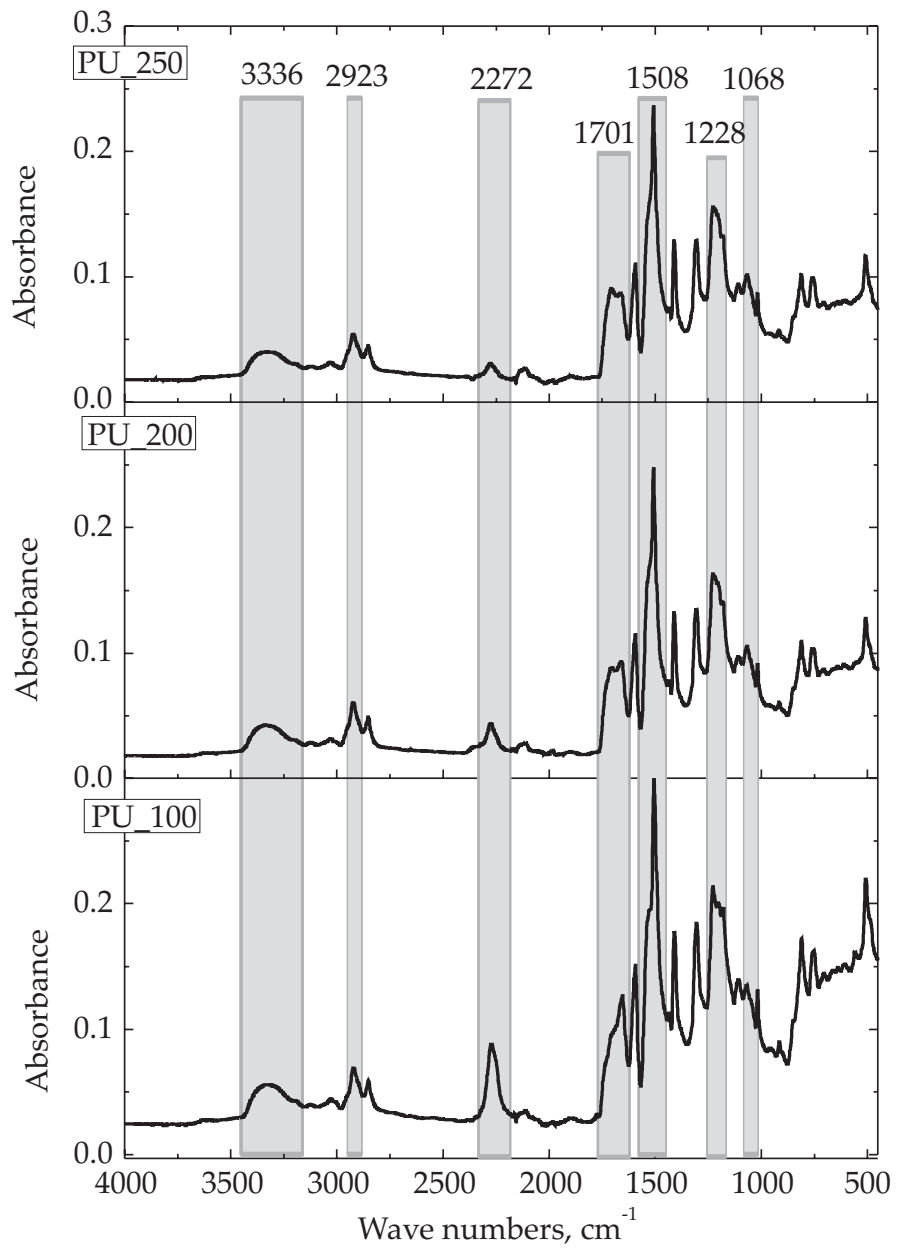

Fig. 7. FT-IR spectra of open-cell PUR foams with biopolyols POL_100, POL_200 and POL_250

characteristic for bonds between carbon and oxygen atoms (in the case of ether bonds) [29]. There are also observed a characteristic peak of unreacted NCO groups at $2272 \mathrm{~cm}^{-1}$. However, it can be seen that the intensity of these peaks decreases as the hydroxyl value of biopolyol increases. This confirms the accelerated effect of the higher hydroxyl value on the reaction of isocyanates

a)

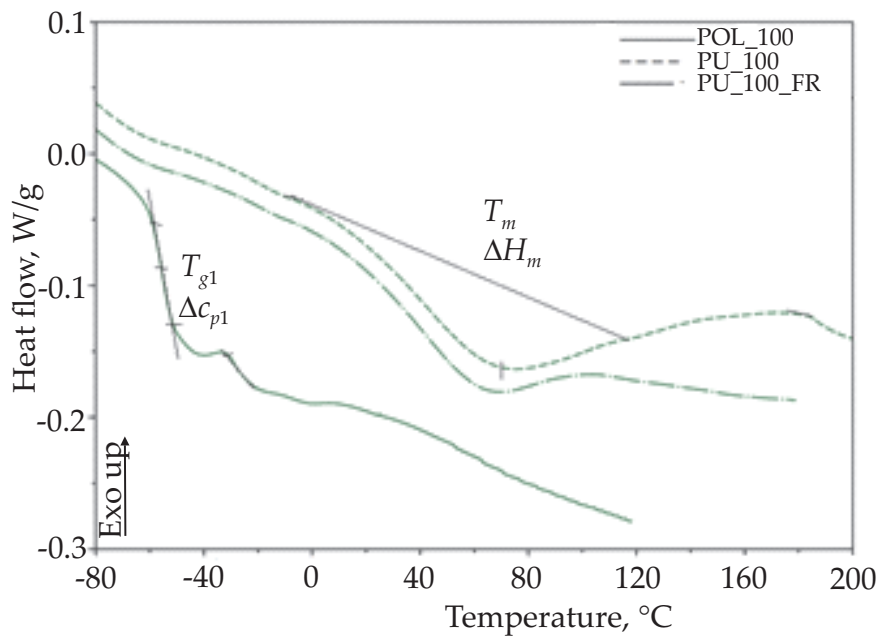

T a b l e 6. Content of urea and urethane bonds, hydrogen bonding index $(R)$ and phase separation degree (DPS) of tested open-cell PUR foams

\begin{tabular}{c|c|c|c|c}
\hline Symbol & $\begin{array}{c}\text { Content } \\
\text { of urea } \\
\text { bonds, \% }\end{array}$ & $\begin{array}{c}\text { Content of } \\
\text { urethane } \\
\text { bonds, \% }\end{array}$ & $R$ & DPS \\
\hline PU_100 & 60 & 40 & 1.22 & 0.55 \\
PU_100_FR & 57 & 43 & 1.14 & 0.53 \\
PU_200 & 58 & 42 & 1.71 & 0.63 \\
PU_200_FR & 62 & 38 & 0.97 & 0.49 \\
PU_250 & 56 & 44 & 2.76 & 0.73 \\
PU_250_FR & 59 & 41 & 1.87 & 0.65 \\
\hline
\end{tabular}

and polyol. This effect is also confirmed by higher maximal temperature during foaming process for PU_200 and PU_250 (Fig. 5). Similar trend was also observed for systems modified with flame retardant.

The influence of hydroxyl value of biopolyols on the content of urea and urethane bonds as well as $R$ and DSP in obtained open-cell PUR foams is shown in Table 6.

The results presented in Table 6 indicate that phase separation depends on the hydroxyl value of biopolyol. The introduction of TEP resulted in the formation of less hydrogen bonds compared to the foam with the same biopolyol but without TEP. Such effect can be caused by plasticizing of PUR matrix with an additive flame retardant [18].

DSC analysis was performed to determine the temperatures corresponding to the physical phase transitions in tested biopolyols and PUR materials using three-steps test method: heating ( $1^{\text {st }}$ cycle $)$ - cooling ( $2^{\text {nd }}$ cycle $)$ - heating ( $3^{\text {rd }}$ cycle). The selected DSC curves are shown in Fig. 8.

The DSC curves show two glass transitions temperatures of biopolyols, nevertheless on cycle number. In the case of PUR materials such characteristic changes for glass transition were not observed during the first cycle of heating. However, the characteristic endothermic peak connected with changes in hard phase were observed for

b)

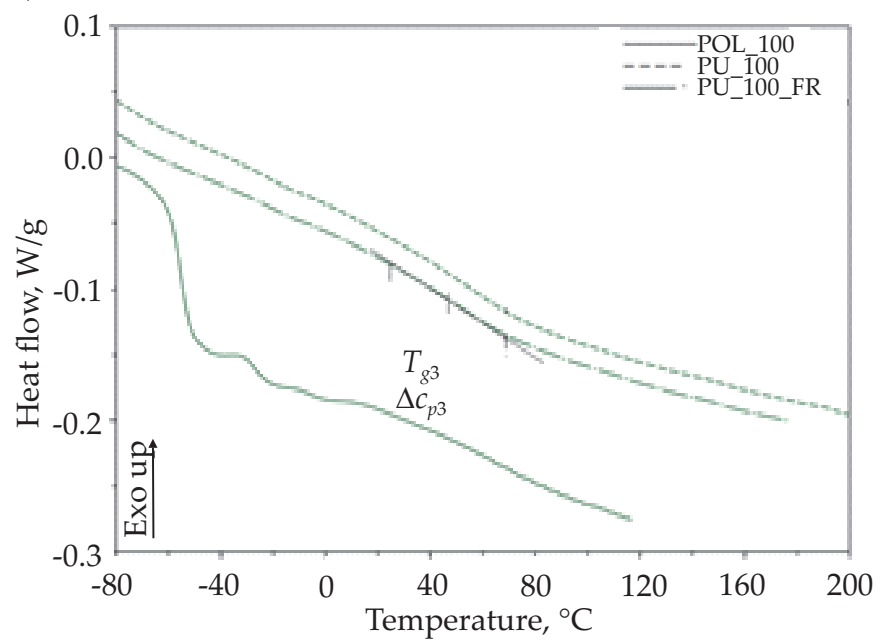

Fig. 8. DSC thermograms of biopolyol POL_100, PU_100 and PU_100_FR in: a) first cycle, b) third cycle of analysis 
T a b l e 7. DSC analysis of biopolyols and open-cell PUR foams

\begin{tabular}{|c|c|c|c|c|c|c|c|c|c|}
\hline Sample & $\begin{array}{c}\text { Heating } \\
\text { cycle }\end{array}$ & $\begin{array}{l}T_{g 1} \\
{ }^{\circ} \mathrm{C} \\
\end{array}$ & $\begin{array}{c}\Delta C_{p 1} \\
\mathrm{~J} /\left(\mathrm{g} \cdot{ }^{\circ} \mathrm{C}\right) \\
\end{array}$ & $\begin{array}{l}T_{g 2} \\
{ }^{\circ} \mathrm{C} \\
\end{array}$ & $\begin{array}{c}\Delta C_{p 2} \\
\mathrm{~J} /\left(\mathrm{g} \cdot{ }^{\circ} \mathrm{C}\right)\end{array}$ & $\begin{array}{l}T_{t} \\
{ }^{\circ} \mathrm{C} \\
\end{array}$ & $\begin{array}{c}\Delta H_{t} \\
\mathrm{~J} / \mathrm{g}\end{array}$ & $\begin{array}{l}\mathrm{T}_{g^{3}} \\
{ }^{\circ} \mathrm{C}\end{array}$ & $\begin{array}{c}\Delta C_{p 3} \\
\mathrm{~J} /\left(\mathrm{g} \cdot{ }^{\circ} \mathrm{C}\right)\end{array}$ \\
\hline \multirow{2}{*}{ POL_100 } & 1 & -55 & 0.53 & -28 & 0.08 & - & - & - & - \\
\hline & 3 & -56 & 0.52 & -28 & 0.08 & - & - & - & - \\
\hline \multirow{2}{*}{ PU_100 } & 1 & - & - & - & - & 66 & 23 & - & - \\
\hline & 3 & - & - & - & - & - & - & 58 & 0.35 \\
\hline \multirow{2}{*}{ PU_100_FR } & 1 & - & - & - & - & 62 & 18 & - & - \\
\hline & 3 & - & - & - & - & - & - & 57 & 0.31 \\
\hline \multirow{2}{*}{ POL_200 } & 1 & -63 & 0.30 & -36 & 0.01 & - & - & - & - \\
\hline & 3 & -63 & 0.30 & -36 & 0.01 & - & - & - & - \\
\hline \multirow{2}{*}{ PU_200 } & 1 & - & - & - & - & 74 & 41 & - & - \\
\hline & 3 & - & - & - & - & - & - & 57 & 0.27 \\
\hline \multirow{2}{*}{ PU_200_FR } & 1 & - & - & - & - & 65 & 28 & - & - \\
\hline & 3 & - & - & - & - & - & - & 56 & 0.21 \\
\hline \multirow{2}{*}{ POL_250 } & 1 & -56 & 0.42 & -30 & 0.12 & - & - & - & - \\
\hline & 3 & -56 & 0.45 & -27 & 0.08 & - & - & - & - \\
\hline \multirow{2}{*}{ PU_250 } & 1 & - & - & - & - & 73 & 47 & - & - \\
\hline & 3 & - & - & - & - & & & 58 & 0.27 \\
\hline \multirow{2}{*}{ PU_250_FR } & 1 & - & - & - & - & 64 & 31 & - & - \\
\hline & 3 & - & - & - & - & - & - & 57 & 0.11 \\
\hline
\end{tabular}

$T_{g 1}$ - glass transition temperature of the polyol fraction with higher particle flexibility;

$\Delta C_{p 1}$ - thermal effects associated with $T_{g 1}$;

$T_{8^{2}}$ - glass transition temperature of the polyol fraction with lower particle flexibility;

$\Delta C_{p 2}$ - thermal effects associated with $T_{g 2}$;

$T_{t}$ - the temperature connected with changes in hard phase;

$\Delta H_{t}$ - the enthalpy of changes in hard phase;

$T_{83}$ - glass transition temperature of hard phase;

$\Delta C_{p 3}$ - thermal effects associated with $T_{83}$.

PUR foams modified and unmodified with flame retardant ( $T_{t}$ in Fig. 8a). This transition is connected with dissociation of hydrogen bonds in hard phase leading to the increase hard phase arrangement. The change in arrangement in the hard phase is confirmed by the occurrence of the glass transition of this phase during the third cycle of DSC analysis ( $T_{83}$ in Fig. $\left.8 \mathrm{~b}\right)$.

All data of DSC analysis are summarized in Table 7.

$T_{g 1}$ and $T_{82}$ of biopolyols POL_100 and POL_250 were higher than that of POL_200. The lowest values $T_{g 1}$ and $T_{g 2}$ of POL_200 can be effect of influence many factors including hydroxyl values, chains length and entanglement.

The glass transition occurs as step increase in the heat capacity $(C p)$ of the sample during heating, which is caused by enhancement of molecular motion in analyzed sample [29, 30].

For all open-cell PUR biofoams endothermic peak on DSC curve, connected with dissociation of hydrogen bonds in hard phase is observed in the range of temperature of $66-74^{\circ} \mathrm{C}$. As the polyol hydroxyl number increases, the enthalpy $\left(\Delta H_{t}\right)$ associated with the dissociation of hydrogen bonds increases. This is consistent with the results of the evaluation index of hydrogen bonds of foams hard phase (Table 6).
The modification of biofoams with additive flame retardant had influence on a decrease of the dissociation temperature $\left(T_{t}\right)$ of hydrogen bonds and the enthalpy of this transition, which correlates with a decrease in the hydrogen bond index $R$ for foams modified with flame retardant (Table 6). It confirms plasticizing effect of additive flame retardant.

In order to evaluate the effect of chemical structure of biopolyols on their thermal stability, the TGA in nitrogen was conducted. The thermal analysis of biofoams was also performed. The loss of mass (TG) and first derivative of the loss of mass (DTG) curves of analyzed polyols and selected biofoams are shown in Fig. 9 and Fig. 10. Their thermal degradation features are summarized in Table 8.

In the case of biopolyols, a two-stage thermal degradation was observed. The first degradation stage occurs in the temperature range of $103-118^{\circ} \mathrm{C}$. The increase of $V_{1}$ and decrease of $T_{5 \%}$ can be associated with the evaporation of unreacted diethylene glycol, which was used to open the oxirane rings at the biopolyol synthesis stage. Based on the GPC analysis, it was found that with increasing hydroxyl value of biopolyol the percentage of diethylene glycol increases in the biopolyol from 2.3 to $5.8 \%$ which correlates with $V_{1}$ and $T_{5 \%}$ changes. In the case of the temperature 


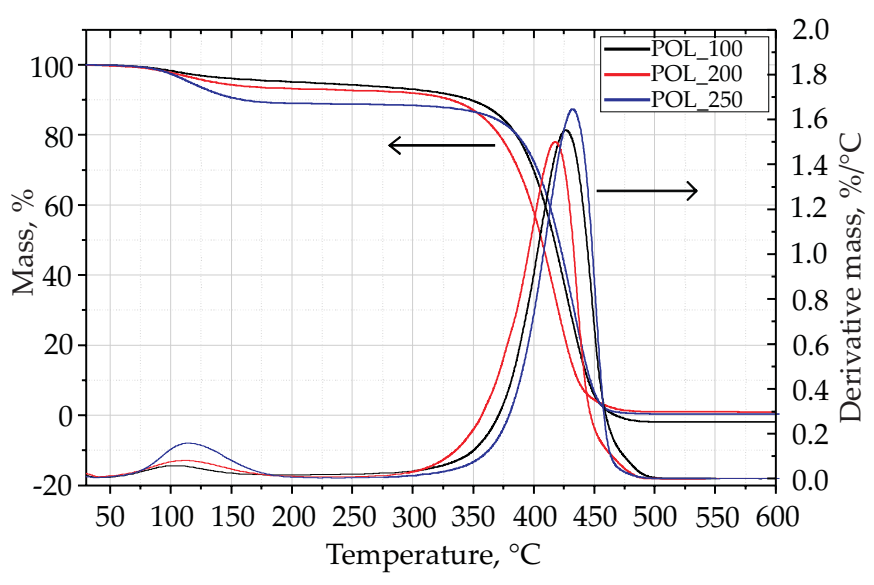

Fig. 9. TG and DTG curves of biopolyols as a function of temperature

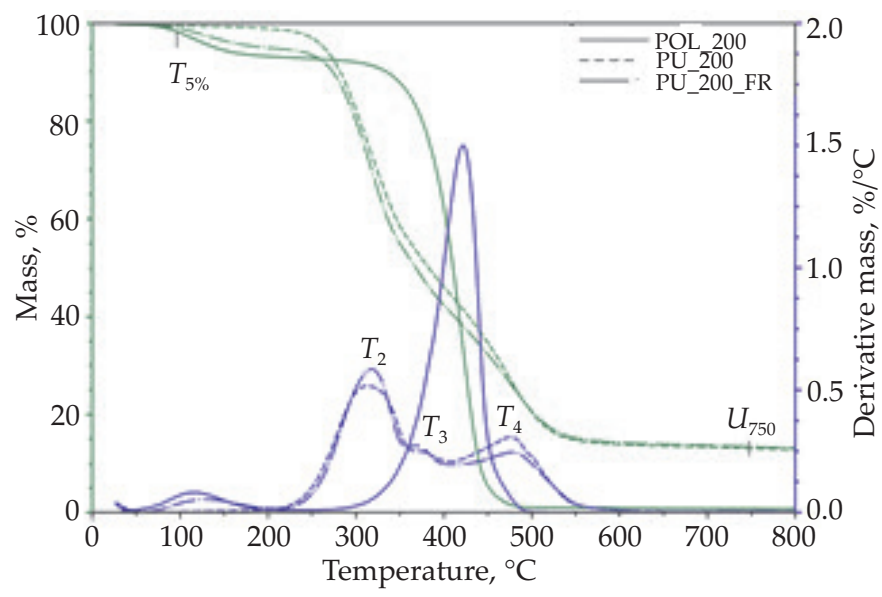

Fig. 10. Thermograms of TG and DTG of POL_200,PU_200 and PU_200_FR

$\mathrm{T}$ a b l e 8. Characteristic of thermal degradation of biopolyols and biofoams

\begin{tabular}{c|c|c|c|c|c|c|c|c|c|c}
\hline Sample & $T_{5 \%}{ }^{\circ} \mathrm{C}$ & $T_{1^{\prime}}{ }^{\circ} \mathrm{C}$ & $V_{1^{\prime}} \% /{ }^{\circ} \mathrm{C}$ & $T_{2^{\prime}}{ }^{\circ} \mathrm{C}$ & $V_{2^{\prime}} \% /{ }^{\circ} \mathrm{C}$ & $T_{3^{\prime}}{ }^{\circ} \mathrm{C}$ & $V_{3^{\prime}} \% /{ }^{\circ} \mathrm{C}$ & $T_{4^{\prime}}{ }^{\circ} \mathrm{C}$ & $V_{4^{\prime}} \% /{ }^{\circ} \mathrm{C}$ & $U_{750^{\prime}} \%$ \\
\hline POL_100 & 208 & 103 & 0.06 & - & - & - & - & 427 & 1.55 & - \\
PU_100 & 270 & - & - & 336 & 0.57 & 385 & 0.32 & 477 & 0.35 & 12.7 \\
PU_100_FR & 255 & - & - & 330 & 0.67 & 363 & 0.36 & 479 & 0.30 & 15.6 \\
\hline POL_200 & 140 & 118 & 0.08 & - & - & - & & 422 & 1.50 & - \\
PU_200 & 264 & - & - & 315 & 0.52 & 375 & 0.25 & 476 & 0.31 & 13.1 \\
PU_200_FR & 199 & 128 & 0.05 & 318 & 0.59 & 371 & 0.27 & 479 & 0.25 & 13.5 \\
\hline POL_250 & 114 & 113 & 0.16 & - & - & - & - & 430 & 1.65 & - \\
PU_250 & 258 & - & - & 325 & 0.65 & - & - & 476 & 0.28 & 15.4 \\
PU_250_FR & 225 & 179 & 0.04 & 322 & 0.56 & - & - & 480 & 0.26 & 13.9 \\
\hline
\end{tabular}

$T_{5 \%}$ - the temperature of $5 \%$ of mass loss;

$T_{1}, T_{2}, T_{3}, T_{4}$ - the temperatures of maximum rate of degradation of 1-4 stages;

$V_{1}, V_{2}, V_{3}, V_{4}$ - the maximum rate of degradation of stages;

$U_{750}$ - char residue at $750{ }^{\circ} \mathrm{C}$.

of the second degradation stage marked as $T_{4}$, the highest value was obtained in the case of POL_250 which may be related to the partial oligomerization of this biopolyol.

Thermal degradation of polyurethanes is a very complex process due to the diversity of their chemical structure. Generally, the thermal degradation of PUR occurs in two main stages. The first stage is associated with thermal degradation of hard segments as a consequence of the relatively low thermal stability of the urethane groups. The second one is related to the soft segments decompositions. It was found that biofoams PU_100 and PU_200 are characterized by three step thermal degradation. In the case of PU_250 biofoam the two-step thermal degradation was observed. Such effect can be associated with $M_{n}$ of biopolyol POL_250. It was confirmed that in the case PUR foams based on a biopolyol with higher molecular weight the degradation of soft segments is observed in the interval $425-475^{\circ} \mathrm{C}$ [29].

In the case of PU_200_FR and PU_250_FR, the additional peaks at 128 and $179^{\circ} \mathrm{C}$ of thermal degradation was observed. Such peaks probably are related to evapora- tion of additive flame retardant. However it is not clear why such peak is not observed for PU_100_FR. One of the hypotheses is low reactivity of the system, which may cause uneven distribution of the flame retardant in the material. Generally, an introduction of flame retardant to PUR system causes decrease of $T_{5 \%}$ in all formulation. However, from application point of view in building construction it is beneficial effect due to acting of flame retardant in gas phase during fire.

\section{CONCLUSIONS}

The presented results confirmed that biopolyol based on used cooking oil can be successfully applied for preparation of open-cell polyurethane foams. The chemical structure and physical properties of biopolyols have essential influence on the properties obtained biofoams. It was concluded that higher viscosity caused by higher content of oligomers in biopolyol makes difficult foaming process, that key-factor in the case of PUR systems for spraying foams. The most promising pro- 
perties were obtained for foams modified with biopolyol characterized by hydroxyl value $200 \mathrm{mg} \mathrm{KOH} / \mathrm{g}$. The results presented in this paper indicate that phase separation in PUR foamed materials depends on the hydroxyl value of biopolyol as well as on introduction of additive flame retardant which resulted in the formation of less hydrogen bonds compared to the foam without this one. Such effect have influence on compressive strength of final products. A practical application of biopolyols based on used cooking oil is possible and sustainable approach in accordance with the rules of Circular Economy in the synthesis of polyurethane foams.

\section{ACKNOWLEDGMENTS}

The authors gratefully acknowledge the support for this work by a research grant from the National Center for Research and Development in Poland under the Lider Program, contract no. LIDER/28/0167/L-8/16/NCBR/2017.

\section{REFERENCES}

[1] Cinelli P., Anguillesi I., Lazzeri A.: European Polymer Journal 2013, 49, 1174. http://dx.doi.org/10.1016/j.eurpolymj.2013.04.005

[2] Informacja Techniczna - Purios HR 2017, 12, 1.

[3] Informacja Techniczna - Purios H 2017, 8, 1.

[4] Informacja Techniczna - Purios $H 77$ 2017, 9, 1.

[5] Informacja Techniczna - Purios E 2018, 28, 1.

[6] Informacja Techniczna - Purios FR 2017, 7, 1.

[7] Informacja Techniczna - Purios ET 2017, 4, 1.

[8] Andrzejewski J., Szostak M., Barczewski M., Łuczak P.: Composites Part B: Engineering 2019, 163, 655. http://dx.doi.org/10.1016/j.compositesb.2018.12.109

[9] Barczewski M., Sałasińska K., Szulc J.: Polymer Testing 2019, 75, 1. http://dx.doi.org/10.1016/j.polymertesting.2019.01.017

[10] Prociak A., Kurańska M., Cabulis U., Kirpluks M.: Polymer Testing 2017, 59, 478. http://dx.doi.org/10.1016/j.polymertesting.2017.03.006

[11] Marcovich N.E., Kurańska M., Prociak A. et al.: Polymer International 2017, 66, 1522. http://dx.doi.org/10.1002/pi.5408

[12] Kalmykova Y., Sadagopan M., Rosado L.: Resources, Conservation and Recycling 2018, 135, 190. http://dx.doi.org/10.1016/j.resconrec.2017.10.034

[13] Marcovich N.E., Kurańska M., Prociak A. et al.: Polymer International 2017, 66, http://dx.doi.org/10.1002/pi.5408

[14] Prociak A., Kurańska M., Cabulis U. et al.: Industrial Crops and Products 2018, 120, 262. http://dx.doi.org/10.1016/j.indcrop.2018.04.046

[15] Prociak A., Malewska E., Kurańska M. et al.: Industrial Crops and Products 2018, 115, 69.

http://dx.doi.org/10.1016/j.indcrop.2018.02.008

[16] Ryszkowska J., Auguścik M., Zieleniewska M. et al.: Polimery 2018, 63, 10. http://dx.doi.org/10.14314/polimery.2018.1.2

[17] Prociak A., Kurańska M., Cabulis U. et al.: Industrial Crops and Products 2018, 120, 262.

http://dx.doi.org/10.1016/j.indcrop.2018.04.046

[18] Gosz K., Haponiuk J., Piszczyk Ł.: Journal of Polymers and the Environment 2018, 26, 3877. http://dx.doi.org/10.1007/s10924-018-1265-9

[19] Ryszkowska J.: Polimery 2012, 57, 777. http://dx.doi.org/10.14314/polimery.2012.777

[20] Choe E., Min D.B.: Journal of Food Science 2007, 72, R77. http://dx.doi.org/10.1111/j.1750-3841.2007.00352.x

[21] Zhang Q., Saleh A.S.M., Chen J., ShenQ.: Chemistry and Physics of Lipids 2012, 165, 662.

http://dx.doi.org/10.1016/j.chemphyslip.2012.07.002

[22] Petrović Z.S., Zlatanić A., Lava C.C.: European Journal of Lipid Science and Technology 2002, 104, 293.

h t t p://d x.d o i.org / $10.1002 / 1438$ -9312(200205)104:5<293::AID-EJLT293>3.0.CO;2-W

[23] Kurańska M., Benes H., Polaczek K. et al.: Journal of Cleaner Production 2019, 230, 162. http://dx.doi.org/10.1016/j.jclepro.2019.05.096

[24] Kurańska M., Cabulis U., Auguścik M. et al.: Polymer Degradation and Stability 2016, 127, 11.

http://dx.doi.org/10.1016/j.polymdegradstab.2016.02.005

[25] Kuranska M., Prociak A., Michalowski S. et al.: Polimery 2016, 61, 625.

http://dx.doi.org/10.14314/polimery.2016.625

[26] Członka S., Bertino M.F., Strzelec K.: Polymer Testing 2018, 68, 135.

http://dx.doi.org/10.1016/j.polymertesting.2018.04.006

[27] Kurańska M., Prociak A., Kirpluks M., Cabulis U.: Industrial Crops and Products 2015, 74, 849.

http://dx.doi.org/10.1016/j.indcrop.2015.06.006

[28] Septevani A.A., Evans D.A.C., Chaleat C. et al.: Industrial Crops and Products 2015, 66, 16. http://dx.doi.org/10.1016/j.indcrop.2014.11.053

[29] Piszczyk Ł., Strankowski M., Danowska M. et al.: European Polymer Journal 2014, 57, 143. http://dx.doi.org/10.1016/j.eurpolymj.2014.05.012

[30] Tanaka R., Hirose S., Hatakeyama H.: Bioresource Technology 2008, 99, 3810. http://dx.doi.org/10.1016/j.biortech.2007.07.007

Received 23 IX 2019. 